\title{
IDENTIFIKASI PLANKTON DI KAWASAN BUDIDAYA RUMPUT LAUT KABUPATEN BANTAENG, SULAWESI SELATAN DENGAN METODE DNA BARCODING
}

\section{IDENTIFICATION OF PLANKTON IN SEAWEED CULTIVATION AREA DISTRICT BANTAENG, SOUTH SULAWESI WITH DNA BARCODING METHOD}

\author{
Margaretha Sandra Apriliyanti ${ }^{1}$, Sutanti $^{2}$, Deny Sapto Chondro Utomo ${ }^{1}$ \\ ${ }^{1}$ Jurusan Perikanan dan Kelautan, Universitas Lampung \\ ${ }^{2}$ Pusat Teknologi Produksi Pertanian, LAPTIAB, BPPT, Serpong \\ Korespondensi: sandra_aleksius@yahoo.co.id
}

\begin{abstract}
DNA barcoding is a method that can be used to identify the plankton by looking at their genetic material. DNA barcoding performed with several stages, i.e. extraction, amplification, purification, and sequencing. The sample used was taken in July 2017 and December 2017 from the area of cultivation of seaweed Bantaeng District, South Sulawesi. This study aims to identify the plankton of the area of seaweed farming in Bantaeng District, South Sulawesi with the method of DNA barcoding using the primer $18 \mathrm{~S} \mathrm{rDNA}$. The results showed that the plankton identified is the zooplankton, Pegurus bernhardus, Canthocalanus pauper, Calanus finmarchicus, dan Copepoda at station B, Acartia longiremis and Subeucalanus pileatus at stations C, and Oithona sp. at stations D and E.
\end{abstract}

Keyword: 18S rDNA, barcoding, identification, plankton

\begin{abstract}
ABSTRAK
DNA barcoding merupakan metode yang dapat digunakan untuk mengidentifikasi plankton dengan melihat materi genetiknya. DNA barcoding dilakukan dengan beberapa tahapan, yaitu ekstraksi, amplifikasi, purifikasi, dan sekuensing. Sampel yang digunakan adalah diambil pada bulan Juli 2017 dan Desember 2017 dari kawasan budidaya rumput laut Kabupaten Bantaeng, Sulawesi Selatan. Penelitian ini bertujuan untuk mengidentifikasi plankton dari kawasan budidaya rumput laut di Kabupaten Bantaeng, Sulawesi Selatan dengan metode DNA barcoding menggunakan primer 18S rDNA. Hasil penelitian menunjukkan bahwa plankton yang teridentifikasi adalah zooplankton, yaitu Pegurus bernhardus, Canthocalanus pauper, Calanus finmarchicus, dan Copepoda pada stasiun B, Acartia longiremis dan Subeucalanus pileatus pada stasiun C, dan Oithona sp. pada stasiun D dan E.
\end{abstract}

Kata kunci: $18 \mathrm{~S}$ rDNA, barcoding, identifikasi, plankton 


\section{PENDAHULUAN}

Plankton merupakan organisme mikroskopik yang dapat terbagi menjadi dua kelompok besar, yaitu fitoplankton dan zooplankton (Nontji 2008). Keberadaan plankton di perairan sangat penting, yaitu berperan sebagai pakan alami bagi ikan (Nontji 2008) serta bioindikator perairan yang dapat digunakan dalam mengevaluasi kesuburan suatu perairan (Umar 2002; Melati et al. 2005).

Plankton memiliki ukuran antara 5um-10mm (Asriyana \& Yuliana 2012) yang tidak dapat dilihat secara kasat mata, oleh karena itu untuk mengetahui jenisnya perlu dilakukan identifikasi lebih lanjut dengan metode khusus. Identifikasi yang umum dilakukan adalah dengan mengamatinya di bawah mikroskop, namun metode ini tidak cukup valid untuk menentukan jenis plankton. Hal ini karena plankton memiliki bentuk serta warna yang hampir serupa. Metode lain yang dapat digunakan adalah DNA barcoding.

DNA barcoding merupakan metode yang dapat digunakan untuk mengidentifikasi plankton dengan melihat materi genetiknya. Metode ini telah banyak digunakan di Indonesia serta negaranegara maju, hal ini karena DNA barcoding mudah untuk dilakukan, membutuhkan waktu yang relatif singkat, dan hanya menggunakan spesimen dalam jumlah yang sedikit.

Metode DNA barcoding telah terbukti efektif serta memberikan hasil yang valid pada beberapa penelitian. Beberapa diantaranya yaitu melihat keanekaragman genetik lamun (Anggraini 2015), analisis keragaman genetik lai-durian (Sunaryo 2015), dan autentikasi produk ikan tenggiri (Maulid \& Nurilmala 2015).

Penelitian ini bertujuan untuk mengidentifikasi plankton dari kawasan budidaya rumput laut di Kabupaten Bantaeng, Sulawesi Selatan dengan metode DNA barcoding menggunakan primer $18 \mathrm{~S}$ rDNA. 18S rDNA merupakan primer universal yang digunakan dalam mengidentifikasi organisme eukariotik.

\section{METODE PENELITIAN}

Penelitian ini dilaksanakan pada Januari sampai Maret 2018 di Laboratorium Bioakuakultur, Pusat Teknologi Produksi Pertanian (PTPP), Badan Pengkajian dan
Penerapan Teknologi (BPPT), Serpong.

Alat yang digunakan dalam penelitian ini adalah tabung mikro 1,5 ml, tabung PCR, centrifuge, refrigirator, $\mathrm{PCR}$ thermal cycler, elekroforesis, nanodrop, kamera, lampu UV, mikropipet, microwave, vortex, waterbath, rak tabung, cool box, inkubator, dan vacum dry.

Bahan yang digunakan dalam penelitian in adalah sampel, primer universal 18S rDNA yang memiliki sekuen forward 5'-CCAGGCASCYGCGGTAAT TCC-3' dan reverse 5'-ACTTTTCGTTCTTGAYRATGA-3' (Van de Peer \& de Wacher 1997 dalam Becerro et al. 2012), Tris-HCl, $\mathrm{NaCl}$, SDS, aquades steril, RNAse, Proteinase-K, larutan PCI, larutan CI, larutan natrium asetat, bubuk agarose, buffer taq, $\mathrm{ddH}_{2} \mathrm{O}$, DNA ladder $(1 \mathrm{~kb})$, TAE $1 \mathrm{x}$, ethidium bromida, TNES-Urea buffer, ethanol absolut 70\% dan 99\%, TE buffer, dan EDTA.

\section{Prosedur Penelitian}

\section{Pengambilan Sampel}

Sampel yang digunakan dalam penelitian ini merupakan koleksi sampel Laboratorium Perikanan, PTPP, BPPT, Serpongyang diambil dari kawasan budidaya rumput laut di Kabupaten Bantaeng, Sulawesi Selatan. Sampel diambil pada pada Juli dan Desember 2017 di stasiun yang berbeda, yaitu stasiun A, B, C, D, dan E. Sampel air di masing-masing stasiun diambil sebanyak 3 kali di 3 titik yang berbeda, setiap titik berjarak lebih kurang $500 \mathrm{~m}$. Total sampel air diambil dari alam sebanyak 1001 kemudian disaring menggunakan plankton net, dan dipindahkan ke botol film sebanyak $30 \mathrm{ml}$. Sampel kemudian diambil sebanyak $1 \mathrm{ml}$ dan disimpan dalam tabung $1,5 \mathrm{ml}$.

\section{Ekstraksi DNA}

Ekstraksi DNA plankton dilakukan dengan menggunakan metode phenol cloroform (Nugroho 1997 dalam Soewardi 2007) yang terdiri dari beberapa tahapan, yaitu sebagai berikut.

1. Penghancuran sel

Sampel plankton dimasukkan ke dalam tabung mikro berukuran 1,5 $\mathrm{ml}$ yang telah berisi $700 \mu$ larutan sel lisis yang terdiri dari $10 \mathrm{mM}$ Tris-HCl, $\mathrm{pH} \mathrm{7,5,125}$ $\mathrm{mM} \mathrm{NaCl}, 10 \mathrm{mM}$ EDTA, pH 7,5, 10\% SDS dan 4 M Urea. Selanjutnya sampel 
ditambahkan $10 \mu \mathrm{l} / \mathrm{ml}$ proteinase-K, divortex, dan diinkubasi pada suhu $37^{\circ} \mathrm{C}$ selama 24 jam (overnight) untuk mempercepat proses lisis sel.

2. Eliminasi RNA

Larutan sel hasil inkubasi ditambah dengan $700 \mu 1$ larutan PCI (Phenol Chloroform Isoamylalcohol) dengan perbandingan 25:24:1, dirotamix selama 5 menit dan disentrifuse dengan kecepatan 7.000 rpm selama 5 menit. Setelah itu larutan supernatan (lapisan paling atas) diambil secukupnya lalu dimasukkan ke dalam tabung mikro $1,5 \mathrm{ml}$ yang baru. Sampel ditambah dengan larutan CI equal dengan volume sampel, dirotamix selama 5 menit, dan disentrifus dengan kecepatan $7.000 \mathrm{rpm}$ selama 5 menit. Larutan supernatan (lapisan paling atas) kemudian diambil secukupnya dan dimasukkan ke dalam tabung mikro $1,5 \mathrm{ml}$ yang baru.

\section{Pengandapan DNA}

Supernatan yang diperoleh dari tahap eliminasi RNA ditambahkan larutan sodium acetat $\left(\mathrm{CH}_{3} \mathrm{COONa} / \mathrm{NaOAc}\right)$ sebanyak $10 \%$ dari volume sampel, dan ethanol 90\% sebanyak 2 kali volume sampel lalu diinkubasi selama 30 menit pada suhu $-20^{\circ} \mathrm{C}$. Sampel kemudian dikeluarkan setelah 30 menit dan diinkubasi pada suhu ruang selama 2 menit agar sampel mencair. Sampel selanjutnya disentrifus dengan kecepatan $14.000 \mathrm{rpm}$ selama 10 menit sampai terlihat lapisan putih (endapan DNA), kemudian supernatan dibuang seluruhnya. Sampel kemudian ditambahkan $1 \mathrm{ml}$ alkohol $70 \%$ dan disentrifus dengan kecepatan 14.000 selama 10 menit sehingga sampel akan membentuk 2 lapisan, yakni bagian atas (supernatan) dan bagian bawah (pellet DNA).

4. Hidrasi DNA

Pada tahap ini sampel dikeringkan dengan membuang supernatan seluruhnya dan dikeringanginkan di atas tisu selama beberapa menit kemudian dikeringkan dengan menggunakan vacum dry selama 1 jam. Setelah kering sampel ditambahkan 40 $\mu 1$ TE buffer dan 1,5 $\mu$ l RNAse. Apabila sampel belum digunakan maka dapat disimpan pada suhu $-20^{\circ} \mathrm{C}$.
Amplifikasi $18 \mathrm{~S}$ rDNA dengan Teknik PCR (Polymerase Chain Reaction)

Bahan yang digunakan yaitu redmix, sampel plankton, $\mathrm{ddH}_{2} \mathrm{O}$, primer (18S rDNA) dicampurkan ke dalam tabung berukuran $1,5 \mathrm{ml}$ dan dibagikan secara merata ke dalam tabung-tabung PCR yang telah disiapkan. Kemudian DNA plankton juga dimasukkan ke dalam masing-masing tabung PCR. Tabung lalu dimasukkan ke dalam mesin PCR yang telah diprogram. Reaksi amplifikasi pada mesin PCR berlangsung dalam beberapa tahap, yaitu denaturasi, annealing, dan ekstensi.

Tahap selanjutnya adalah elektroforesis, yakni dengan menggunakan gel agarose $1 \%$ yang dilarutkan dengan menggunakan larutan TAE $1 \mathrm{x}$ sebanyak $100 \mathrm{ml}$. Elektroforesis dijalankan dengan tegangan 100 Volt selama 1 jam, kemudian gel yang telah dielektroforesis direndam dalam larutan ethidium bromida dengan konsentrasi $1 \mathrm{mg} / \mathrm{ml}$ selama 15 menit. Gel lalu diletakkan di atas UV transilluminator dan dilakukan pengambilan foto. PCR dilakukan dengan menggunakan primer universal, yaitu primer 18S rDNA

\section{Purifikasi Gel}

Purifikasi gel atau agar dilakukan dengan menggunakan GenepHlow Gel/PCR Kit.

\section{Sekuensing}

Sekuensing pada penelitian ini dilakukan dengan menggunakan metode Sanger. Metode ini dikenal juga sebagai metode dideoksi Sanger ataupun metode chain termination. Selama perkembangannya metode Sanger telah dapat dilakukan secara lebih cepat, yakni dengan menggunakan alat sequencer.

\section{Analisis Data}

Hasil yang didapatkan dari tahapan sekuensing adalah data yang berupa susunan basa nukleotida yang dapat dianalisis lebih lanjut, yaitu dengan menginput data ke program BLAST pada GenBank yang dapat diakses melalui situs www.ncbi.nlm.nih.gov. 


\section{HASIL DAN PEMBAHASAN}

\section{Pengambilan Sampel}

Sampel yang diambil pada Juli 2017 diberi kode A1.1, A1.2, A1.3, B1.1, B1.2, B1.3, C1.1, C1.2, C1.3, D1.1, D1.2, D1.3, E1.1, E1.2, E1.3, dan sampel yang diambil pada Desember 2017 diberi kode A2.1, A2.2, A2.3, B2.1, B2.2, B2.3, C2.1, C2.2, C2.3, D2.1, D2.2, D2.3, E2.1, E2.2, E2.3.

\section{Ekstraksi DNA}

Konsentrasi dan kemurnian DNA plankton terdapat pada Tabel 1 . Konsentrasi DNA tertinggi adalah $101,0 \mathrm{ng} / \mu \mathrm{l}$ pada sampel E1.2 dengan kemurnian 1,66, dan kosentrasi terendah $2,6 \mathrm{ng} / \mu \mathrm{l}$ pada sampel A2.2 dengan kemurnian 1,3. Konsentrasi minimal DNA yang dapat diamplifikasi adalah $10 \mathrm{ng} / \mu \mathrm{l}$ dengan kemurnian antara 1 sampai 1,8. Nilai konsentrasi serta kemurnian DNA dipengaruhi oleh beberapa faktor, diantaranya adalah pemisahan antara supernatan dan pelet serta pengeringan pelet DNA yang kurang sempurna (Arya 2015).

Sampel yang telah diekstraksi selanjutnya akan diamplifikasi. Sampel yang dapat diamplifikasi hanya 21 sampel, yaitu B1.1, B1.2, B1.3, C1.2, C1.3, D1.1, D1.2, D1.3, E1.1, E1.2, E1.3, A2.1, A2.2, $\mathrm{A} 2.3, \mathrm{~B} 2.2, \mathrm{~B} 2.3, \mathrm{C} 2.2, \mathrm{C} 2.3, \mathrm{D} 2.1, \mathrm{E} 2.2$ dan E2.3.

Tabel 1. Hasil pengukuran konsentrasi dan kemurnian DNA plankton

\begin{tabular}{ccc}
\hline $\begin{array}{c}\text { Sampel } \\
\text { Juli 2017 }\end{array}$ & $\begin{array}{c}\text { Konsentrasi } \\
\text { DNA (ng/ } \boldsymbol{\mu l )}\end{array}$ & $\begin{array}{c}\text { Kemurnian } \\
\text { DNA }\end{array}$ \\
\hline A1.1 & 4,7 & 1,2 \\
A1.2 & 2,6 & 1,3 \\
A1.3 & 3,2 & 1,25 \\
B1.1 & 17,3 & 1,70 \\
B1.2 & 31,4 & 1,47 \\
B1.3 & 22,3 & 1,82 \\
C1.1 & 4 & 2,81 \\
C1.2 & 16,4 & 2,22 \\
C1.3 & 72,1 & 2,11 \\
D1.1 & 11,9 & 1,92 \\
D1.2 & 13,6 & 2,48 \\
D1.3 & 19,4 & 2,13 \\
E1.1 & 31,3 & 1,93 \\
E1.2 & 57,4 & 2,03 \\
E1.3 & 12,9 & 2,36 \\
\hline
\end{tabular}

\begin{tabular}{ccc}
\hline $\begin{array}{c}\text { Sampel } \\
\text { Desember } \\
\mathbf{2 0 1 7}\end{array}$ & $\begin{array}{c}\text { Konsentrasi } \\
\text { DNA (ng/ } \mathbf{l 1})\end{array}$ & $\begin{array}{c}\text { Kemurnian } \\
\text { DNA }\end{array}$ \\
\hline A2.1 & 18,2 & 1,69 \\
A2.2 & 10,5 & 1,35 \\
A2.3 & 12,5 & 1,62 \\
B2.1 & 8,1 & 1,73 \\
B2.2 & 13,4 & 1,75 \\
B2.3 & 13,9 & 1,63 \\
C2.1 & 6,5 & 1,27 \\
C2.2 & 11,1 & 1,40 \\
C2.3 & 18,4 & 1,72 \\
D2.1 & 12,0 & 1,56 \\
D2.2 & 4,0 & 0,98 \\
D2.3 & 7,5 & 1,46 \\
E2.1 & 101,0 & 1,66 \\
E2.2 & 41,0 & 1,48 \\
E2.3 & 20,1 & 1,60 \\
\hline
\end{tabular}

\section{Amplifikasi 18S rDNA dengan Teknik PCR (Polymerase Chain Reaction)}

Visualisasi hasil amplifikasi terdapat pada Tabel 2. Amplifikasi dilakukan menggunakan primer $18 \mathrm{~S}$ rDNA dengan suhu annealing optimum, yaitu $53^{\circ} \mathrm{C}$. Primer ini telah berhasil mengamplifikasi DNA plankton yang ditandai dengan munculnya pita DNA yang berukuran sekitar 424 bp yang tersaji pada Tabel 2.

\section{Purifikasi}

Hasil purifikasi yang telah diperoleh kemudian diukur kembali konsentrasi serta kemurniannya menggunakan nanodrop untuk mengetahui apakah sampel tersebut dapat memasuki tahap sekuensing. Hasil pengukuran konsentrasi dan kemurnian sampel yang telah dipurifikasi terdapat pada Tabel 3. 
Tabel 2. Visualisasi hasil amplifikasi

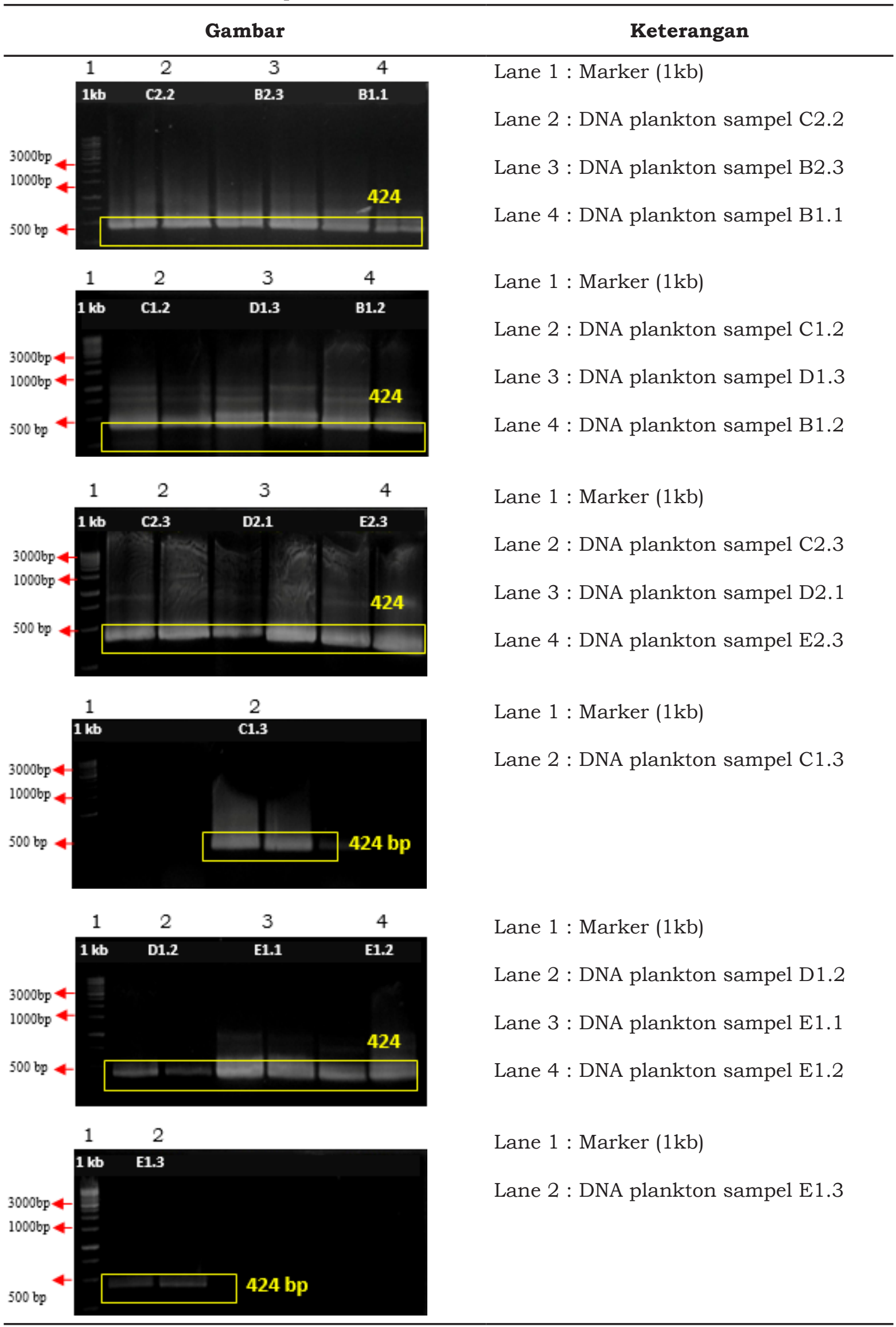




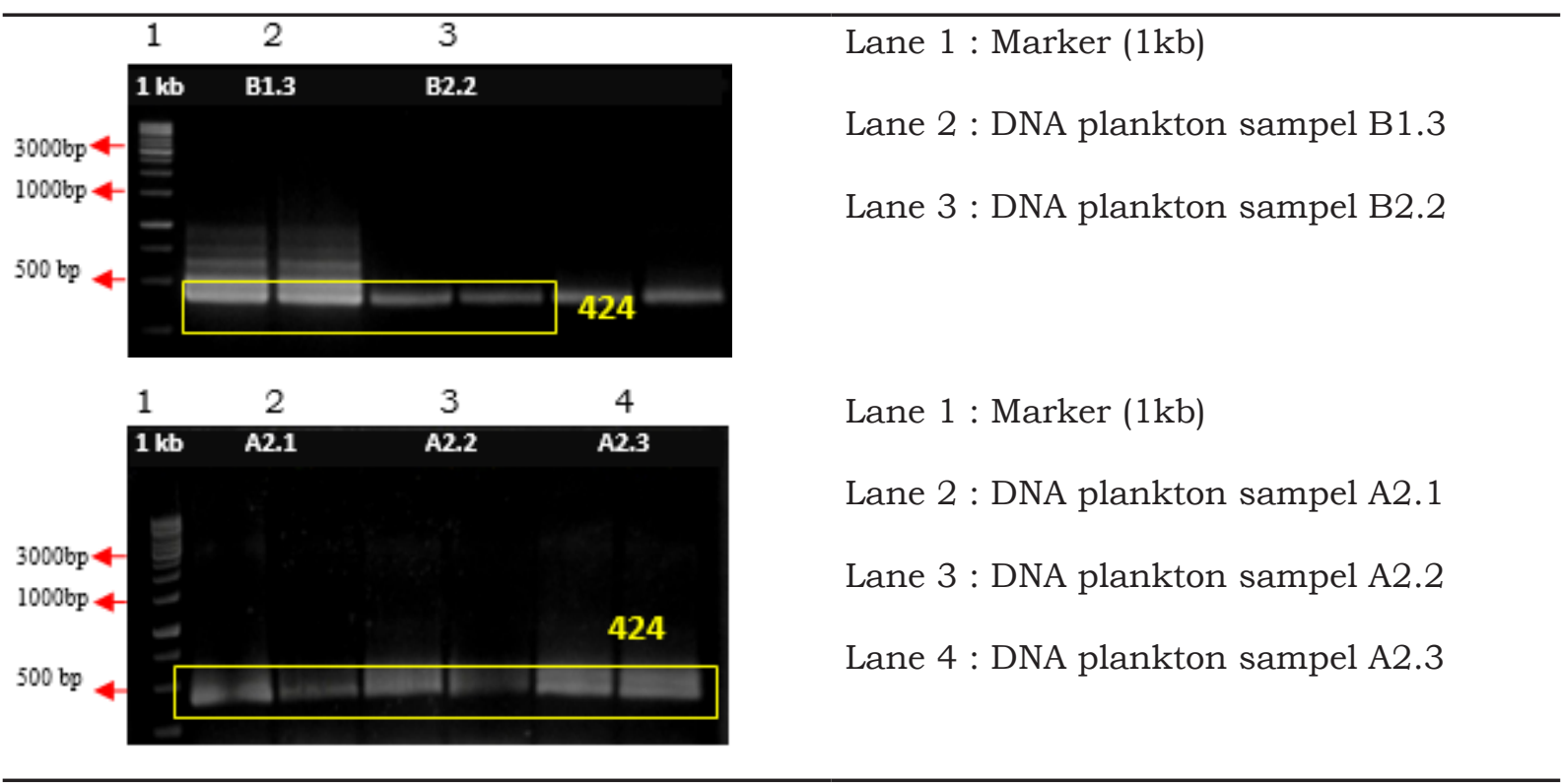

Tabel 3. Hasil pengukuran konsentrasi sampel hasil purifikasi

\begin{tabular}{ccc}
\hline Sampel & \multicolumn{2}{c}{ Purifikasi } \\
\cline { 2 - 3 } $\mathbf{2 0 1 7}$ & $\begin{array}{c}\text { Konsentrasi } \\
\text { (ng/ } \boldsymbol{\mu l} \text { ) }\end{array}$ & Kemurnian \\
\hline C1.2 & 48,8 & 1,99 \\
C1.3 & 43,1 & 1,90 \\
D1.2 & 60,3 & 2,6 \\
D1.3 & 38,2 & 2,01 \\
E1.1 & 55,2 & 1,87 \\
E1.2 & 52,6 & 1,87 \\
E1.3 & 29,6 & 1,81 \\
B1.1 & 39,3 & 2,22 \\
B1.2 & 29,4 & 1,98 \\
B1.3 & 44,44 & 1,88 \\
\hline
\end{tabular}

\begin{tabular}{|c|c|c|}
\hline \multirow{2}{*}{$\begin{array}{c}\text { Sampel } \\
\text { Desember } \\
2017\end{array}$} & \multicolumn{2}{|c|}{ Purifikasi } \\
\hline & $\begin{array}{c}\text { Konsentrasi } \\
(\mathrm{ng} / \mu \mathrm{l})\end{array}$ & Kemurnian \\
\hline A2.1 & 32,1 & 1,90 \\
\hline A2.2 & 33,1 & 1,94 \\
\hline A2.3 & 66,4 & 1,89 \\
\hline B2.2 & 25,2 & 1,95 \\
\hline B2.3 & 28,4 & 1,86 \\
\hline $\mathrm{C} 2.2$ & 37,1 & 1,54 \\
\hline $\mathrm{C} 2.3$ & 48,2 & 1,86 \\
\hline $\mathrm{D} 2.1$ & 57,1 & 1,90 \\
\hline E2.3 & 84 & 1,87 \\
\hline
\end{tabular}

Sampel yang dapat dipurifikasi sebanyak 19 sampel. Sampel pada bulan Juli adalah C1.2, C1.3, D1.2, D1.3, E1.1, E1.2, E1.3, B1.1, B1.2, dan B1.3, sedangkan sampel pada bulan Desember 2017 adalah $\mathrm{A} 2.1, \mathrm{~A} 2.2, \mathrm{~A} 2.3, \mathrm{~B} 2.2, \mathrm{~B} 2.3, \mathrm{C} 2.2, \mathrm{C} 2.3$, D2.1, dan E2.3. Tabel 3 menunjukkan bahwa konsentrasi sampel yang telah dipurifikasi berkisar antara 25,2 ng/ $\mu 1$ sampai dengan $84 \mathrm{ng} / \mu \mathrm{l}$ serta kemurnian yang berkisar antara 1,81 sampai dengan 2,6. Suatu sampel dapat disekuensing apabila memiliki konsentrasi $25 \mathrm{ng} / \mu \mathrm{l}$ atau lebih, sedangkan kemurnian yang baik berkisar antara 1 sampai dengan 2 .

\section{Sekuensing}

Sampel sebanyak 19 yang telah dipurifikasi kemudian masuk ke tahap sekuensing. Sekuensing merupakan proses untuk menentukan susunan basa (A, T, G, dan C) yang membentuk DNA. Sekuensing dilakukan dengan menggunakan alat sequencer. Metode sekuensing DNA umumnya menggunakan primer untuk mengawali sintesis DNA yang berfungsi untuk menentukan titik awal sintesis dan arah reaksi sekuens DNA (Muladno 2002), sehingga primer juga perlu disertakan dalam proses sekuensing. Hasil dari sekuensing 
merupakan susunan basa nukleotida yang kemudian dapat digunakan untuk mengidentifikasi plankton dari kawasan budidaya rumput laut Kabupaten Bantaeng, Sulawesi Selatan. Contoh hasil sekuensing terdapat pada Gambar 1.

\section{Analisis Data}

Analisis data yang dilakukan adalah mengidentifikasi hasil sekuensing yang telah didapatkan. Identifikasi dilakukan dengan menginput susunan basa nukleotida yang telah didapatkan dari hasil sekuensing ke program BLAST (basic local alignment search tool) pada GenBank dengan mengakses situs www.ncbi.nlm.nih.gov. Hasil BLAST terdapat pada Tabel 4.

Sampel yang teridentifikasi sebanyak 9 sampel, yaitu B2.2, C2.3, D2.1, E1.2, E2.3, B1.2, C1.3, B1.1, dan B2.3. Sampel yang tidak teridentifikasi dapat terjadi karena dipengaruhi oleh beberapa faktor, salah satunya yaitu genom yang terdapat pada sampel hanya berjumlah sedikit sehingga tidak terdeteksi saat proses sekuensing. Hasil BLAST pada Tabel 4 menunjukkan bahwa plankton yang teridentifikasi merupakan zooplankton dengan jenis yang berbeda-beda pada setiap sampel.

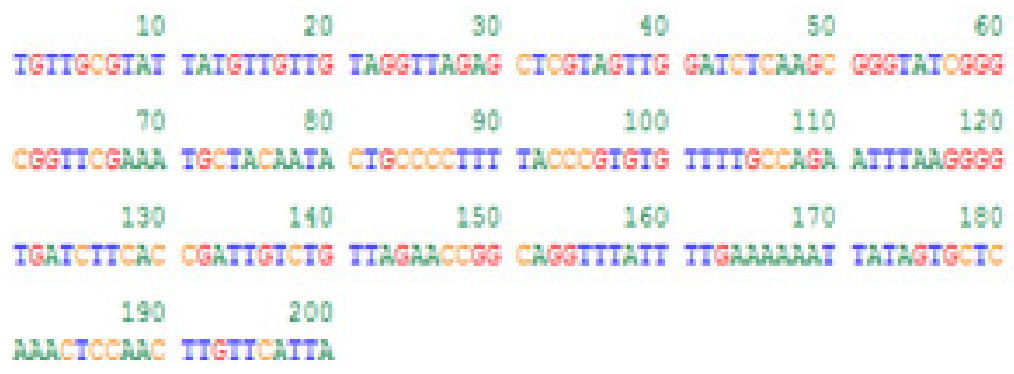

Gambar 1. Hasil Sekuensing

Tabel 4. Hasil identifikasi plankton menggunakan program BLAST

\begin{tabular}{cclc}
\hline Sampel & $\begin{array}{c}\text { Ukuran } \\
\text { BP }\end{array}$ & \multicolumn{1}{c}{ Jenis Plankton } & $\begin{array}{c}\text { Persentase Kemiripan } \\
\text { dan No.Aksesi }\end{array}$ \\
\hline B2.2 & 276 & Pegurus bernhardus & $97 \%$ KY454197.1 \\
C2.3 & 396 & Acartia longiremis & $90 \%$ GU969156.1 \\
D2.1 & 396 & Oithona sp. & $86 \%$ JF781539.1 \\
E1.2 & 240 & Temora turbinata & $88 \%$ GU969211.1 \\
E2.3 & 354 & Oithona sp. & $90 \%$ JF781539.1 \\
B1.2 & 260 & Canthocalanus pauper & $93 \%$ GU969164.1 \\
C1.3 & 399 & Subeucalanus pileatus & $93 \%$ GU969188.1 \\
B1.1 & 368 & Calanus finmarchicus & $80 \%$ MF993124. \\
B2.3 & 295 & Copepoda & $98 \%$ MG811792.1 \\
\hline
\end{tabular}

\section{KESIMPULAN}

Berdasarkan penelitian yang telah dilakukan menunjukkan bahwa plankton yang teridentifikasi dari kawasan budidaya rumput laut di Kabupaten Bantaeng, Sulawesi Selatan menggunakan metode DNA barcoding adalah Pegurus bernhardus, Canthocalanus pauper, Calanus finmarchicus, dan Copepoda pada stasiun B, Acartia longiremis dan Subeucalanus pileatus pada stasiun $\mathrm{C}$, dan Oithona $s p$. pada stasiun $\mathrm{D}$ dan $\mathrm{E}$.

\section{UCAPAN TERIMA KASIH}

Ucapan terima kasih penulis sampaikan kepada Direktur Teknologi Produksi Pertanian (PTPP) beserta staf peneliti dan perekayasa terutama bidang perikanan, Kepala Lab. PTPP BPPT di Laboratoria Pengembangan Teknologi Industri Agro dan Biomedika (LAPTIAB), Badan Pengkajian dan Penerapan Teknologi (BPPT) di Kawasan Puspiptek Serpong, yang telah mendukung dan memfasilitasi kegiatan penelitian ini. 


\section{DAFTAR PUSTAKA}

Anggraini, N.P. 2015. Sistematika Molekuler DNA Barcoding dan Keanekaragaman Genetika Lamun di Pulau Panggang, Pulau Pramuka dan Pulau Karya, Kepulauan Seribu, Jakarta. (Skripsi). Institut Pertanian Bogor, Bogor. 51 hlm.

Arya, D.N.F. 2015. Identifikasi Pola Haplotipe DNA Mitokondria Udang Jari (Metapenaeus elegans) Segara Anakan Kabupaten Cilacap Jawa Tengah Menggunakan Enzim Retriksi HindIII. (Skripsi). Universitas Islam Negeri Maulana Malik Ibrahim, Malang. $69 \mathrm{hlm}$.

Asriyana dan Yuliana. 2012. Produktivitas Perairan. Bumi Aksara, Jakarta. 125 hlm.

Maulid, D.Y. dan Nurilmala, M. 2015. DNA Barcoding untuk Autentikai Porduk Ikan Tenggiri (Scomberomorus sp.). Jurnal Akuatika: 154-160.

Melati, Herman, Listari. 2005. Komunitas Fitoplankton Sebagai Bio-Indokator Perairan di Teluk Jakarta. Depok, Seminar Nasional MIPA 2005. 75 hlm.

Muladno. 2002. Teknologi Rekayasa Genetika. Pustaka Wirausaha Muda, Bogor. 120 hlm.
Nontji, A. 2008. Plankton Laut. LIPI Press, Jakarta. $331 \mathrm{hlm}$.

Nugroho, E. 1997. Practical Manual on Detection of DNA Polymorphism in Fish Population Study. Bulletin of Marine Science and Fisheris: 109-129.

Sunaryo, W. 2015. Review: Aplikasi DNA Barcoding Untuk Analisis Keragaman Genetik Lai-Durian (Durio zibethius $\mathrm{x}$ kutejensis) Asal Kalimantan Timur. Prosiding Seminar Nasional Masyarakat Biodiversitas Indonesia, 1: 1275-1276.

Umar, N.A. 2002. Komposisidan Kelimpahan Fitoplankton Hubungannya dengan Kelimppahan Zooplankton (Kopepoda) dan Larva Kepiting Bakau (Scylla spp.). [Skripsi]. Bogor: Institut Pertanian Bogor. 164 hlm.

Van de Peer, Y. dan de Wachter, R. 1997. Evolutionary Relationships Among the Eukaryotic Crown Taxa Takingg ito Account Site-to-Site Rate Variation in 18A rRNA. Journal of Molecular Evolution 45, 619-630 dalam Becerro, M.A., Maria, J.U., Manuel, M., Xavier, T. 2012. Advances in Spone Science: Phylogeny, Systematics, Ecology Vol. 61. Academic Press is an imprint of Elsevier, London. 